\title{
Application of a photogrammetric kinematic model for prediction of lung volumes in adolescents: a pilot study
}

Wagner L Ripka ${ }^{*^{*}}$, Leandra Ulbricht ${ }^{2+}$ and Pedro M Gewehr ${ }^{1 \dagger}$

\author{
*Correspondence: ripka.w@gmail. \\ com \\ ${ }^{\dagger}$ Equal contributors \\ ${ }^{1}$ Graduate Program in Electrical \\ Engineering and Computer Science, \\ Federal University of Technology- \\ Paraná, Av. Sete de Setembro, 3165 \\ Curitiba, Brazil \\ Full list of author information is \\ available at the end of the article
}

\begin{abstract}
Background: There are several ways to measure the respiratory system, among them inductance plethysmography and three-dimensional kinematic analysis, methods of high cost and difficult transportability. The objective of this study was to correlate respiratory volumes obtained by spirometry standard equipment with a biomechanical model photogrammetric analysis of adolescents.

Methods: We evaluated 50 subjects of both genders, aged between 14 and 17 years old, excluding those with respiratory obstruction or restriction. Stickers with markers, there was a five-point mapping for anatomical modeling and photogrammetry, with each evaluated in supine position, was sought to test the Forced Vital Capacity (FVC). The test was filmed and repeated three times. Images of the films were extracted for the moment of maximum exhalation and inhalation of proof with better breathing. With the use of a commercial software, defined the respiratory volumes to the thorax and abdomen.
\end{abstract}

Results: The photogrammetric analysis has found values strongly correlated with the spirometric measurements of FVC (0.812), forced expiratory volume in one second $\left(F E V_{1}-0.708\right)$, Peak Expiratory Flow (PEF - 0.762) in addition to post test performed Inspiration (IP- 0.816). There was a higher ventilatory mobility for boys than girls for Lower Chest and Lower and Upper Abdomen. It was possible to reach a regression $R^{2}=0.866$ for proof of $F V C$ and $R^{2}=0.776$ for IP with the use of photogrammetry, presenting a standard error of 0.353 and 0.451 , respectively.

Conclusions: Photogrammetry can be used to study thoracoabdominal movements by applying analytical two-dimensional and three-dimensional images acquired using a video camera being, applicable and reproducible.

Keywords: Photogrammetry, Spirometry, Adolescent

\section{Background}

The respiratory performance is the result of a complex set of organs, muscles and bone structures that work simultaneously to generate the phenomenon of ventilation, vital for humans [1]. The measures of ventilation reflects physiological and functional aspects, with potential use in the clinical, epidemiological and sports areas [2].

Technologies that aim to measure and evaluate respiratory performance are fundamental for health professionals' decision making [3]. Thus, tools that produce

(c) 2014 Ripka et al.; licensee BioMed Central Ltd. This is an Open Access article distributed under the terms of the Creative Commons Attribution License (http://creativecommons.org/licenses/by/2.0), which permits unrestricted use, distribution, and reproduction in any medium, provided the original work is properly credited. The Creative Commons Public Domain Dedication waiver (http:// creativecommons.org/publicdomain/zero/1.0/) applies to the data made available in this article, unless otherwise stated. 
consistent values, with objectivity, reproducibility and relevance, are designed to facilitate such work [4].

Most of the available methods for evaluation volumes, capacities, limitations and breathing patterns in an efficient and non-invasive way are, to Brazilian health area, expensive and often difficult to transport, and it requires trained technicians to operate [5-7]. These limitations restrict pulmonary function test and measures of ventilation to large laboratories, preventing their popularization in many places, such as schools, basic health units and clubs [8].

Considering the reality of Brazilian public health system, there is a need to develop low cost tools and methodologies for respiratory measures that provide consistent and reproducible results. Photogrammetry, a process dating from 19th century, enables obtaining quantitative information about a system that will be evaluated by inserting metric dimensions into images. Its association with static and kinematic measures has indicated satisfactory results [9-12], being considered as a new way for the aggregation of high-level evidence in the evaluation of form and quality of movement [13-15].

This process, incorporated to the respiratory measures, showed good results in two-dimensional respiratory analysis, proving to be a reliable, reproducible and affordable method $[8,16]$. However, studies with adolescents, such as threedimensional ventilation simulations, show that there are still gaps to be filled. Therefore, the objective of this study was to test the applicability of a biomechanical model of three-dimensional (3D) photogrammetric analysis for predicting lung volumes in adolescents, in comparison to spirometry, the standard method for respiratory measures.

\section{Methods}

An exploratory-descriptive study was carried out with a sample of 50 individuals (19 boys and 21 girls), aged between 14 and 17 years old. The assessments included anthropometry, spirometric measurements and photogrammetric analysis. Parents or guardians of all participants signed a formal letter of consent. This study was approved by the Ethics Committee of the UFPR under protocol no. 01655012.6.0000.0102.

Body mass $(\mathrm{kg})$, height $(\mathrm{m})$, body mass index $(\mathrm{BMI}-\mathrm{kg} / \mathrm{m} 2)$ and thorax length $(\mathrm{cm})$ were collected for the anthropometric assessment.

Body mass was measured by using a $100 \mathrm{~g}$ resolution mechanical scale (Filizola ${ }^{\mathrm{ru}}$ ). Height was assessed by using a stadiometer $(0.1 \mathrm{~cm}$ resolution), fixed and coupled to the scale. Data collection followed recommendations described in the literature [17].

BMI enables classification of participants as underweight, normal, overweight and obese. In order to measure thorax length, participants stood up with their arms away from their bodies. An anthropometric caliper (WCS model; $0.1 \mathrm{~mm}$ resolution) was positioned in line with the xiphoid process of each participant, who were asked to take a deep breath during the measurement.

The respiratory evaluation was a selection criterion for the study. The procedures followed recommendations of the Brazilian Society of Pulmonology and Phthisiology [18]. Each participant, after previous training, was asked to perform three forced vital capacity (FVC) tests using a bi-directional digital spirometer (CareFusion - Microloop model) with accuracy of $10 \mathrm{ml}$ for volume and $0.03 \mathrm{l} / \mathrm{s} \pm 3 \%$ for flow. 
In addition to FVC values, the maneuver allowed to obtain the peak expiratory flow (PEF), the forced expiratory volume in one second (FEV1), deep inspiration (DI) and the Tiffeneau index (FEV1/FVC). Participants with a Tiffeneau index below 80\% were excluded, since this is an indicative of respiratory obstruction or restriction [18].

Seven adolescents had a Tiffeneau index lower than $80 \%$, and three had possible restriction due to low FVC. Therefore, 40 individuals were analyzed for the treatment of images.

Participants with a Tiffeneau index greater than $80 \%$ underwent a new respiratory assessment that included three new tests in dorsal decubitus position. These three maneuvers were filmed, and the measurement with the best expiratory value was used in the photogrammetric analysis.

A Sony camcorder HDX-100 supported on a $1.50 \mathrm{~m}$ tripod and placed $2 \mathrm{~m}$ away from the participant was used. Adhesive markers (PIMACO ${ }^{\circ}$ ) with known diameter $(13 \mathrm{~mm})$ were placed on the participants on the projections of the umbilicus (COd), the inferior angle of the 10th rib $(A C d)$, the manubrium sterni $(M E d)$, the xiphoid process $(\mathrm{AXd})$ and the right anterior superior iliac spine (EId) (Figure $1 \mathrm{~A}$ and $\mathrm{B}$ ). The determination of anatomic location was given by following the methodology of palpatory anatomy by Tixa [19].

The Windows Movie Maker software was used to extract the frames related to the moments of maximum expiration and inspiration. These images were transferred to AutoCad $^{\circledR}$ version 2012 for three-dimensional extrapolation (Figure 2) and obtaining thoracic and abdominal volumes. All calculations were carried out after the dimension correction of each image, based on the adhesive marker with known diameter. The 3D extrapolation was made from the insertion of the thoracic length in the 2D image, through the extrusion tool available in the software.

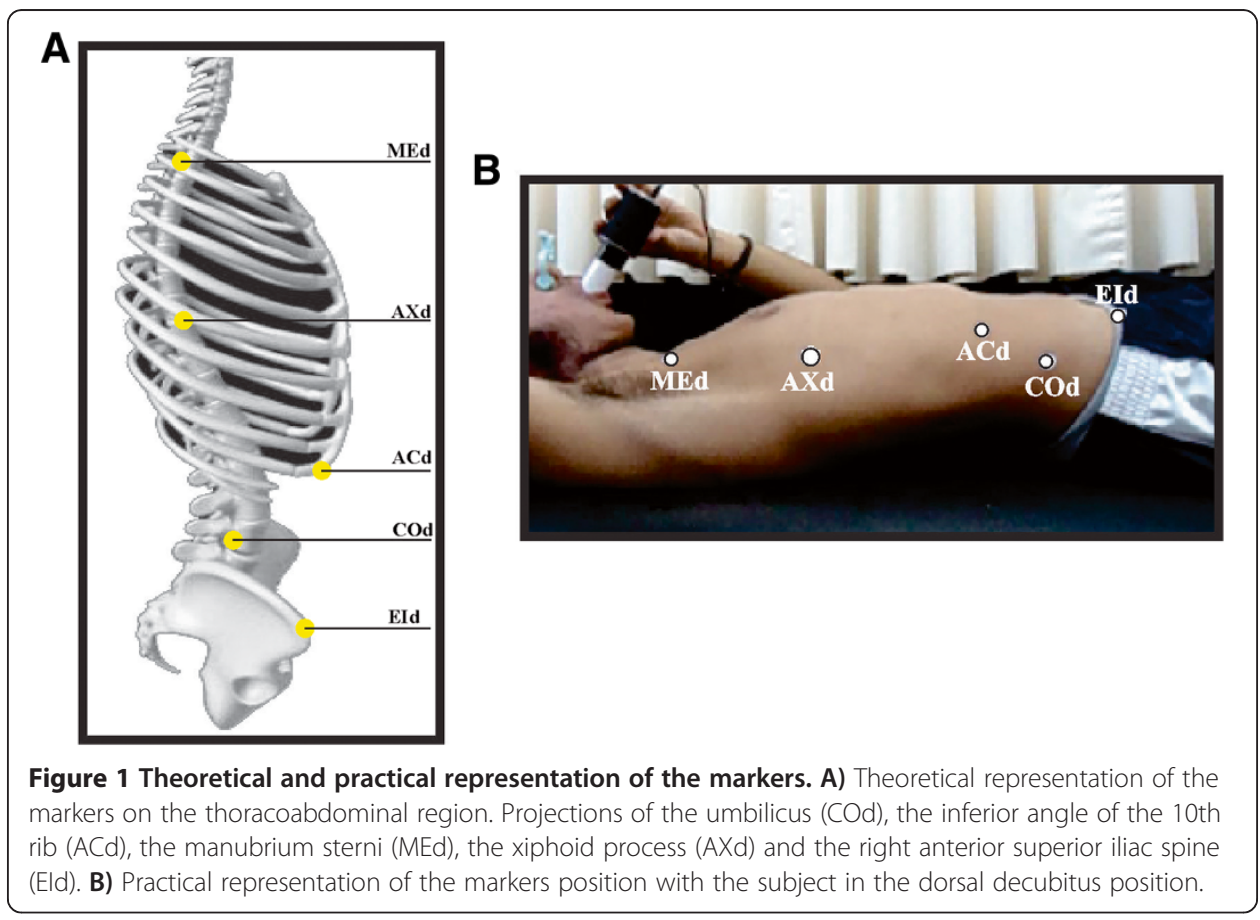




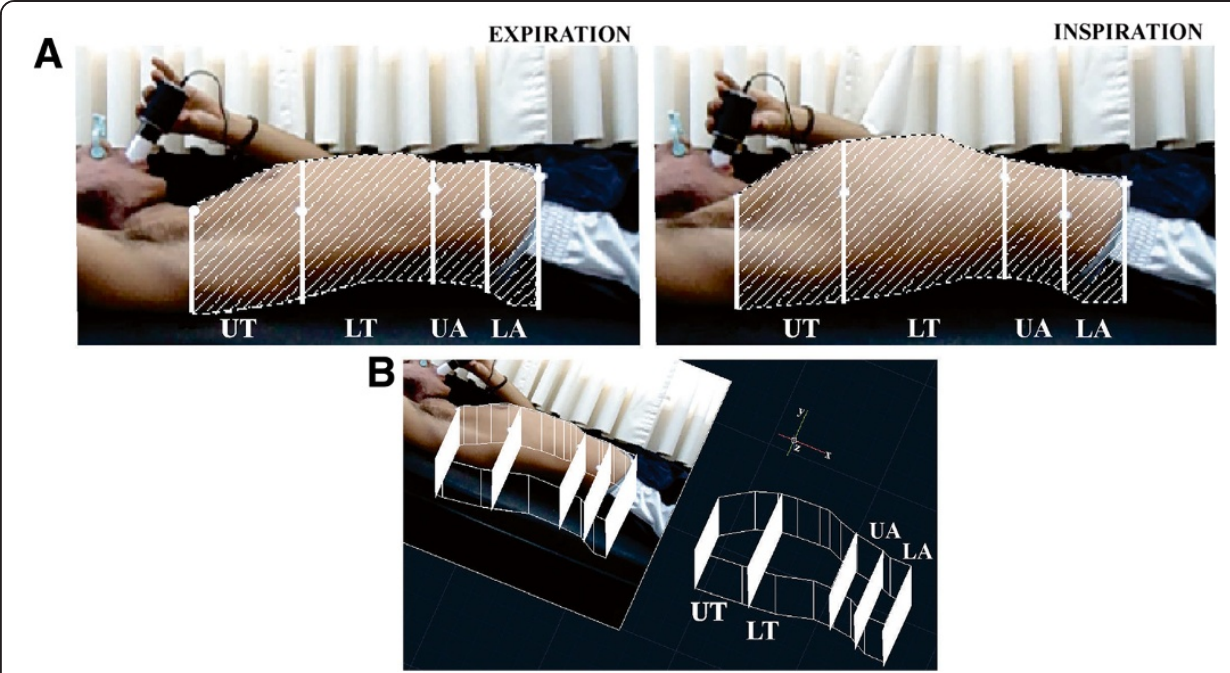

Figure 2 Representations of the photogrammetric model. A) Representation of the photogrammetric model for maximal inspiration and expiration. B) Photogrammetric model of three-dimensional extrapolation from two-dimensional images. In both images, the thoracoabdominal section shows the Upper Thorax (UT), Upper Abdomen (UA), Lower Thorax (LT) and Lower Abdomen (LA). The sets UT-LT and UA-LA form the Total Thorax Area (TT) and Total Abdominal Area (TA), respectively.

The results were initially analyzed by position and dispersion measurements (mean and standard deviation). Then, the Pearson's correlation test was applied to verify the hypothesis between respiratory volumes and surface thoracoabdominal displacement. The multiple regression test was applied to structure equations for FVC and DI prediction. Finally, the Bland-Altman test was used to verify the agreement between the new method applied and the standard spirometric procedure. The limits were defined with the mean bias \pm SD 1.96 [20]. Statistical significance was set at $\mathrm{p}<0.05$.

\section{Results}

Table 1 shows mean, minimum and maximum values of the anthropometric, respiratory and photogrammetric measures. Age (years), body mass $(\mathrm{kg})$, height $(\mathrm{m}), \mathrm{BMI}(\mathrm{kg}$. $\mathrm{m}-2)$ and thorax length $(\mathrm{cm})$ are the variables for the anthropometric values. Forced expiratory volume in one second (FEV1) (l), forced vital capacity (FVC) (l), peak expiratory flow (PEF) (l/s) and deep inspiration (DI) were part of the pulmonary function assessment (l). The photogrammetric analysis relates to the volumes of Upper Thorax, Lower Thorax and Total Thorax, Upper Abdomen, Lower Abdomen and Total Abdomen, and Thoracoabdominal region. The volumetric values were described for inspiration and expiration.

All participants showed normal BMIs and spirometric values recommended by the Brazilian Society of Pulmonology and Phthisiology [18]. Analyzing the volumetric variability between inspiration and expiration, the values $14.9 \%, 29.7 \%$ and $21.6 \%$ were obtained for UT, LT and TT, respectively, whereas $23.4 \%, 8.4 \%$ and $14.7 \%$ were obtained for UA, LA and TA, respectively. These values indicate greater recruitment of the UT region followed by the UA region. In the analysis of inspiration, the proportion of TT and TA use in relation to the thoracoabdominal area was also evaluated: $69.6 \%$ for TT against 30.4\% for ABT was observed. 
Table 1 Sample table title

\begin{tabular}{|c|c|c|c|c|}
\hline Variables & Mean & Standard deviation & Minimum & Maximum \\
\hline \multicolumn{5}{|c|}{ Anthropometric values } \\
\hline Age (years) & 15.4 & 1.0 & 14.0 & 17.0 \\
\hline Body mass (kg) & 61.3 & 12.3 & 43.5 & 87.0 \\
\hline Height (m) & 1.66 & 0.1 & 1.52 & 1.87 \\
\hline $\mathrm{BMI}\left(\mathrm{kg} \cdot \mathrm{m}^{-2}\right)$ & 22.1 & 3.5 & 17.6 & 32.3 \\
\hline Thorax $(\mathrm{cm})$ & 25.5 & 1.9 & 21.5 & 29.5 \\
\hline \multicolumn{5}{|l|}{ Pulmonary function } \\
\hline FEV1 (I) & 3.22 & 0.82 & 1.77 & 5.16 \\
\hline FVC (I) & 3.87 & 0.91 & 2.39 & 5.81 \\
\hline $\operatorname{PEF}(1 / \mathrm{s})$ & 6.50 & 2.41 & 2.84 & 12.15 \\
\hline $\mathrm{DI}(\mathrm{I})$ & 3.59 & 0.91 & 2.05 & 5.40 \\
\hline \multicolumn{5}{|c|}{ Photogrammetric analysis (expiration) } \\
\hline Upper thorax (I) & 7.32 & 2.44 & 4.30 & 15.22 \\
\hline Lower thorax (I) & 5.90 & 2.21 & 2.51 & 11.12 \\
\hline Total thorax (I) & 13.21 & 4.14 & 7.82 & 26.34 \\
\hline Upper abdomen (I) & 2.56 & 0.87 & 0.91 & 5.19 \\
\hline Lower abdomen (I) & 3.56 & 1.56 & 0.74 & 8.41 \\
\hline Total abdomen (l) & 6.12 & 2.2 & 2.53 & 13.18 \\
\hline Thoracoabdominal (I) & 19.33 & 6.18 & 10.36 & 39.52 \\
\hline \multicolumn{5}{|c|}{ Photogrammetric analysis (inspiration) } \\
\hline Upper thorax (I) & 8.41 & 2.62 & 4.93 & 15.17 \\
\hline Lower thorax (I) & 7.65 & 3.25 & 3.05 & 17.04 \\
\hline Total thorax (I) & 16.06 & 5.24 & 9.75 & 30.79 \\
\hline Upper abdomen (I) & 3.16 & 1.19 & 1.13 & 6.87 \\
\hline Lower abdomen (I) & 3.86 & 1.83 & 0.87 & 9.39 \\
\hline Total abdomen (I) & 7.02 & 2.75 & 2.66 & 15.69 \\
\hline Thoracoabdominal (I) & 23.08 & 7.77 & 12.41 & 46.31 \\
\hline
\end{tabular}

Mean, standard deviation, minimum and maximum values for age, weight, height, BMl, thorax length, forced expiratory volume in one second (I), forced vital capacity (I), peak expiratory flow (I/s), deep inspiration (I) (DI) and photogrammetric analysis for expiration and inspiration tests.

Table 2 shows the correlation values between the pulmonary function and the photogrammetric results. Correlations between all compartments evaluated by photogrammetry with the respiratory variables can be noted, and the highest values are for FVC and DI with the Total Volumetric Mobility. Volumetric Mobility values were obtained through the difference between the inspired and expired thoracoabdominal volumes, both calculated in the $3 \mathrm{D}$ extrapolation.

Finally, photogrammetric analysis was employed for the prediction of the values obtained with a spirometer, through linear regression. The model for FVC prediction had correlation $\mathrm{R}=0.931\left(\mathrm{R}^{2}=0.866\right)$, standard deviation $=0.353$ and $\mathrm{p}<0.05$ (Equation 1). It was also possible to predict the DI value with correlation $\mathrm{R}=0.881$ $\left(R^{2}=0.815\right)$, standard deviation $=0.451$ and $p<0.05$ (Equation 2$)$. Height $(m)$, thorax length $(\mathrm{cm})$ and total volumetric mobility (l) were used in equations (1) and (2): 
Table 2 Another sample table title

\begin{tabular}{|c|c|c|c|c|}
\hline & FEV1 & FVC & PEF & DI \\
\hline \multicolumn{5}{|l|}{ Inspiration } \\
\hline Upper thorax (I) & 0.625 & 0.680 & 0.658 & 0.701 \\
\hline Lower thorax (I) & 0.670 & 0.709 & 0.715 & 0.660 \\
\hline Total thorax (I) & 0.728 & 0.780 & 0.773 & 0.760 \\
\hline Upper abdomen (I) & 0.480 & 0.513 & 0.571 & 0.549 \\
\hline Lower abdomen (I) & 0.610 & 0.642 & 0.625 & 0.636 \\
\hline Total abdomen (I) & 0.616 & 0.664 & 0.665 & 0.663 \\
\hline Thoracoabdominal (I) & 0.708 & 0.761 & 0.756 & 0.747 \\
\hline \multicolumn{5}{|l|}{ Expiration } \\
\hline Upper thorax (I) & 0.586 & 0.628 & 0.635 & 0.646 \\
\hline Lower thorax (I) & 0.603 & 0.613 & 0.604 & 0.550 \\
\hline Total thorax (I) & 0.668 & 0.698 & 0.697 & 0.674 \\
\hline Upper abdomen (I) & 0.398 & 0.470 & 0.519 & 0.474 \\
\hline Lower abdomen (I) & 0.613 & 0.619 & 0.635 & 0.604 \\
\hline Total abdomen (I) & 0.594 & 0.627 & 0.658 & 0.618 \\
\hline Thoracoabdominal (I) & 0.659 & 0.691 & 0.701 & 0.672 \\
\hline Total volumetric mobility & 0.708 & 0.812 & 0.762 & 0.816 \\
\hline
\end{tabular}

Correlation between the inspired and expired thoracoabdominal values obtained by photogrammetry and respiratory volumes obtained by spirometry.

$$
\begin{aligned}
\text { FVC }=-8.572+5.108 & \times \text { Height }+0.138 \times \text { Thorax }+0.120 \\
& \times \text { Total Volumetric Mobility } \\
\text { DI }=-6.373+3.751 & \times \text { Height }+0.122 \times \text { Thorax }+0.163 \\
& \times \text { Total Volumetric Mobility }
\end{aligned}
$$

A method of agreement was tested with the Bland-Altman plot, as shown in Figure 3 for FVC and in Figure 4 for DI. There was no significant bias for any of the predictions.

\section{Discussion}

All participants were considered as normal through spirometry analysis, with average values of $3.22 \pm 0.82 \mathrm{l}$ for FEV1, $3.87 \pm 0.91 \mathrm{l}$ for FVC and $6.50 \pm 2.41 \mathrm{l} / \mathrm{s}$ for PEF.
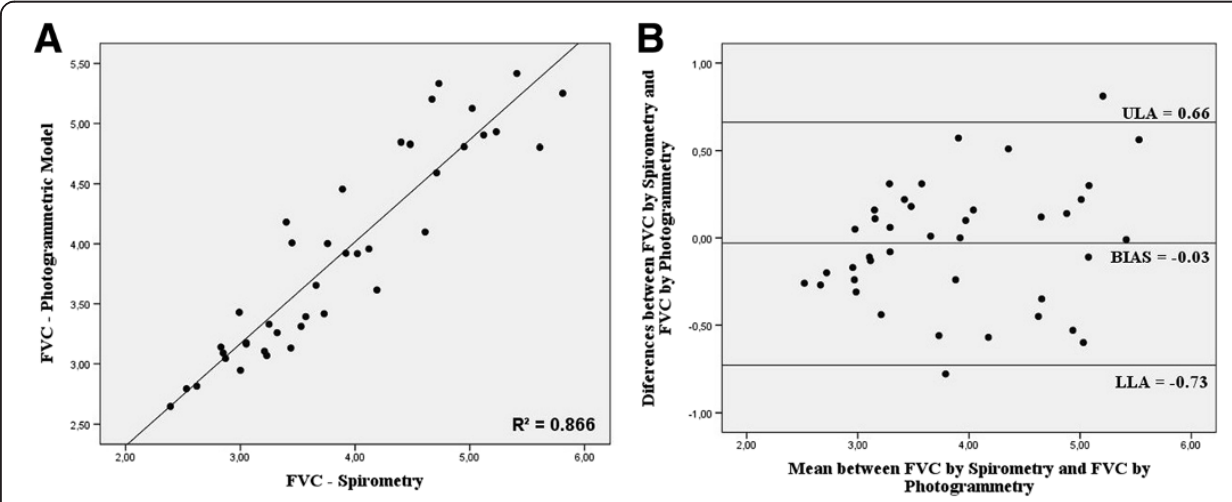

Figure 3 Bland-Altman plot by photogrammetric and FVC. A) Plot for the values predicted by photogrammetric analysis and for FVC by spirometry. B) Bland-Altman analysis of agreement. ULA = Upper Limit of Agreement; LLA = Lower Limit of Agreement. 

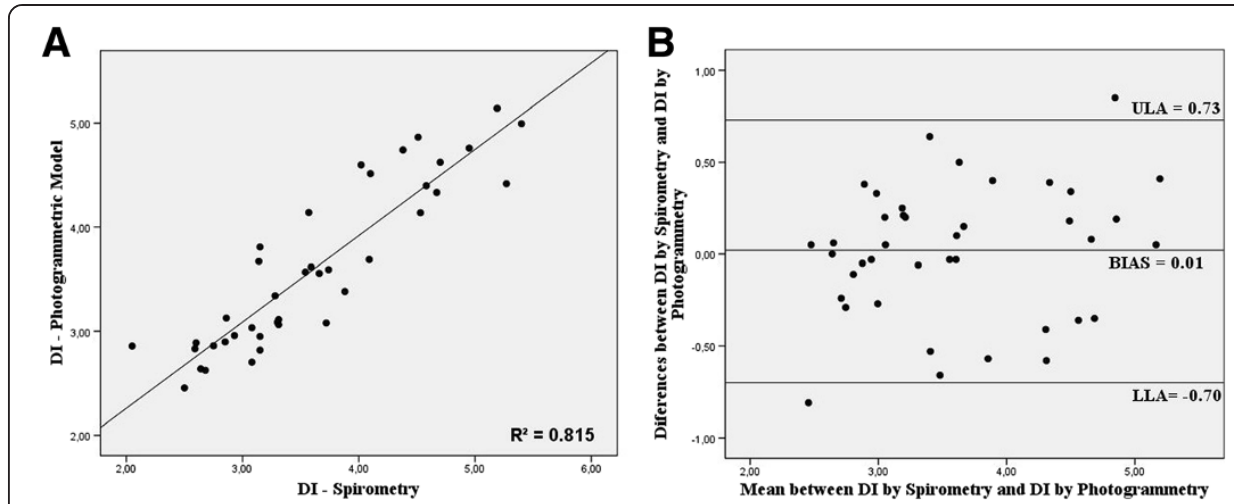

Figure 4 Bland-Altman plot by photogrammetric and DI. A) Plot for the values predicted by photogrammetric analysis and for DI by spirometry. B) Bland-Altman analysis of agreement. ULA: Upper Limit of Agreement; LLA = Lower Limit of Agreement.

Spirometry was used for comparing photogrammetric data, since spirometry test is considered an important tool for the measures, quantification and diagnostic follow-up of pulmonary function $[21,22]$.

The methodology applied in this study allowed the analysis of the contribution of the thoracic and abdominal compartments in the inspiration process of the participants, showing greater expansibility for the LT and UA regions. The ratios of $69.6 \%$ for TT and $30.4 \%$ for TA are similar to those found in the literature $[8,14]$. Mechanically interconnected by the diaphragm, compartments $\mathrm{TX}$ and $\mathrm{AB}$ work synchronously to capture respiratory gases, yet possess independent movement $[8,23,24]$, allowing greater expansion of one region over another.

In this study, FVC and DI predictions showed a good correlation with spirometry, since respiratory capacities suffer numerous technical impacts, including: training to perform the tests and biological individualities [25], observing values of $R^{2}=0.866$ and $\mathrm{R}^{2}=0.815$, respectively.

Prediction equations for respiratory values are found in the literature to establish predicted values for variables such as FVC, FEV1 and FVC however, variability can reach up to $20 \%$ of the actual value, especially for FVC [26-28]. The maximum variability, represented by the standard deviation, resulted $7.9 \%$ for FVC and $8.2 \%$ for DI. Regression tests are seen in the respiratory prediction equations, which has height as the primary independent variable $[29,30]$. In this study, the inclusion of thoracoabdominal mobility values computed by $3 \mathrm{D}$ photogrammetry, as well as the inclusion of the thoracic length, minimized the errors inherent in predicting lung volumes [31].

Quantifying the respiration in its cycles is important because it allows the analysis of respiratory patterns that may represent efficiency or deficiency in energy demand. About 3 to $5 \%$ of the energy consumed by the body occurs in the quiet or basal ventilation [32], and this value can be even higher $(30 \%)$ in individuals with some degree of obstruction or restriction [1].

The quantification of respiratory movements based on the variations in lung volumes, through the displacement of thoracoabdominal structures and associated with photographic images, is a facilitating strategy to quantitative identification of imbalances in the respiratory system. Moreover, this method has been proven effective, of easy applicability and transportability $[8,12,14,31]$. 
The spirometry is considered a low-cost method in developed countries, however the reality of public health in developing nations shows otherwise. In Brazil, a country of this study, it is the duty of the state to secure health for all residents, however the lack of equipment and lack of maintenance are typical themes in news. Data show that the Brazilian public health system provides 1.9 device per million inhabitants and estimates that $30 \%$ of all technology park is not used properly or is abandoned [33], reinforcing the need for creation of new methodologies.

Although the results found in this work, 3D photogrammetric analysis lacks comparison to validated laboratory methods used to study respiratory kinematics, such as inductance plethysmography and analysis of three-dimensional images.

\section{Conclusions}

The equations developed based on the suggested process for predicting FVC and DI showed high correlation, and their agreement was tested by the Bland-Altman plot.

Respiratory analysis through images is a relatively simple and fast process; it involves easily transportable tools, allowing the application of respiratory movements tests in several places, including schools, gyms and clubs. In addition, photogrammetric studies in adolescents represent an innovation in the literature, as previous studies in respiratory imaging analysis have been restricted to children and adults.

This research achieved the proposed objectives; however, a photogrammetric analysis during effortless ventilation maneuvers is suggested for future studies, in order to test the sensitivity of the method in small thoracoabdominal displacements. There is also the need for application of the method in different populations, such as individuals evaluated in different positions, since this is a variable that changes respiratory values.

Competing interests

The authors declare non-financials competing interests.

Authors' contributions

WLR participated in the design of the study, performed the statistical analysis and wrote the manuscript; LU participated in the mythology and study review; PMG participated in its design and coordination. All authors read and approved the final manuscript.

Acknowledgements

Thanks to the Coordenação de Aperfeiçoamento de Pessoal de Nível Superior (CAPES), for granting a master's scholarship.

\footnotetext{
Author details

${ }^{1}$ Graduate Program in Electrical Engineering and Computer Science, Federal University of Technology-Paraná, Av. Sete de Setembro, 3165 Curitiba, Brazil. ${ }^{2}$ Graduate Program in Biomedical Engineering, Federal University of

Technology-Paraná, Av. Sete de Setembro, 3165 Curitiba, Brazil.

Received: 23 December 2013 Accepted: 23 February 2014

Published: 27 February 2014

\section{References}

1. West JB: Fisiologia Respiratória. 8th edition. São Paulo: Artmed; 2010

2. Powers SK, Howley ET: Fisiologia do Exercício: Teoria e Aplicação ao Condicionamento e ao Desempenho. 6th edition. Barueri: Manole; 2009.

3. Morrow JR, Jackson A, Disch J, Mood D: Medida e Avaliação do Desempenho Humano. Porto Alegre: Artmed; 2003.

4. Tritschler K, Barrow HM, McGee R: Medida e Avaliação em Educação Física e Esportes de Barrow \& McGee. 5th edition. São Paulo: Manole; 2003.

5. Da Gama AEF: Eletromiografia e Pletismografia óptico-eletrônica na Avaliação Respiratória. Dissertação: Universidade Federal de Pernambuco, Departamento de Fisioterapia; 2011.

6. Pereira CAC, Jansen JM, Barreto SSM, Marinho J, Sulmonett N, Dias RM: Espirometria. J Pneumol 2002, 28:1-82.

7. Loula CMA, Pachêco AL, Sarro KJ, Barros RML: Análise de volumes parciais do tronco durante a respiração por videogrametria. Rev Bras Biomec 2004, 9:21-27.
} 
8. Ripka WL, Ricieri DV, Ulbricht L, Neves EB, Guimarães IA, Romaneli E, Stadnik AMW: Biophotogrammetry model of respiratory motion analysis applied to children. In 34th Annual International Conference of the IEEE Engineering in Medicine and Biology Society (EMBC), 2012, San Diego, 2012 Annual International Conference of the IEEE Engineering in Medicine and Biology Society, Volume 1; 2012:1952-1955.

9. Baraúna MA, Duarte F, Sanchez HM, Canto RST, Malusá S, Campelo-Silva CD, Ventura-Silva RA: Evaluation of the static balance lower limb amputeers by means of computerized biophotogrammetry. Rev Bras de Fisio 2006, 10:83-90.

10. Hochman B, Nahas FX, Ferreira LM: Photography in medical research. Acta Cir Bras 2005, 20:19-25.

11. Ricieri DV, Rosário Filho NA: Impacto de fatores externos sobre a mecânica respiratória avaliada por um modelo fotogramétrico específico: biofotogrametria. J Bras Pneumol 2008, 34:702-706.

12. Ricieri DV, Costa JR, Rosário Filho NA: Impacto da asma sobre a postura corporal de crianças entre 8 e 14 anos analisada pela biofotogrametria. Acta Fisiátrica 2008, 15:214-219.

13. Barros RML, Brenzikofer R, Leite NJ, Figueroa PJ: Desenvolvimento e avaliação de um sistema para análise cinemática tridimensional de movimentos humanos. Rev Bras Eng Biomed 1999, 15:79-86.

14. Ricieri DV, Rosário Filho NA: Efetividade de um modelo fotogramétrico para a análise da mecânica respiratória toracoabdominal na avaliação de manobras de isovolume em crianças. J Bras Pneumol 2009, 35:144-150.

15. Perin $A$, Ulbricht L, Ricieri D, Neves E: Utilização da biofotogrametria para a avaliação da flexibilidade de tronco. Rev Bras Med Esporte 2012, 18:176-180.

16. Ricieri DV: Princípios processuais da Biofotogrametria e sua adaptação para medidas em estudos sobre movimentos respiratórios toracoabdominais. In Dissertação. Curitiba: Universidade Federal do Paraná, Departamento de Ciências da Saúde; 2008.

17. Petroski EL: Antropometria: Técnicas e Padronizações. Blumenau: Nova Letra; 2007.

18. SBPT: (Sociedade Brasileira de Pneumologia e Tisiologia) - Provas de função pulmonar em crianças e adolescentes. J Pneumol 2002, 28:207.

19. Tixa S: Atlas de Anatomia Palpatória do Pescoço, do Tronco e do Membro Superior. São Paulo: Manole; 2000

20. Bland JM, Altman DG: Statistical methods for assessing agreement between two methods of clinical measurement. Lancet 1986, 327:307-310.

21. Subbarao P, Lebecque P, Corey M, Coates AL: Comparison of spirometric reference values. Pediatr Pulmonol 2004, 37:515-522.

22. Parreira VF, Bueno CJ, França DC, Vieira DSR, Pereira DR, Britto RR: Padrão respiratório e movimento toracoabdominal em indivíduos saudáveis: influência da idade e do sexo. Rev Bras Fisioter 2010, 14:411-416.

23. Konno K, Mead J: Measurement of the separate volume changes of rib cage and abdomen during breathing. J Appl Physiol 1967, 22:407-422.

24. Romagnoli I, Gorini M, Gigliotti F, Bianchi R, Lanini B, Grazzini M, Stendardi L, Scano G: Chest wall kinematics, respiratory muscle action and dyspnoea during arm vs. leg exercise in humans. Acta Physiol 2006, 188:63-73.

25. ATS ATS: American Thoracic Society, Lung function testing: selection of reference values and interpretative strategies. Am Rev Respir Dis 1991, 144:1202-1218.

26. Glindmeyer HW III: Predictable confusion. J Occup Med 1981, 23:845

27. Kulich M, Rosenfeld M, Campbell J, Kronmal R, Gibson RL, Goss CH, Ramsey B: Disease-specific reference equations for lung function in patients with cystic fibrosis. Am J Resp Crit Care Med 2005, 172:885-891.

28. Wu Y, Zhang Z, Gang B, Love EJ: Predictive equations for lung function based on a large occupational population in North China. J Occup Health 2009, 51:471-477.

29. Polgar G: Pulmonary Function Testing in Children: Techniques and Standards. Philadelphia: Saunders Philadelphia; 1971.

30. Hsu KHK, Jenkins DE, Hsi BP, Bourhofer E, Thompson V, Tanakawa N, Hsieh GSJ: Ventilatory functions of normal children and young adults-Mexican-American, white, and black. I. Spirometry. J Pediatr 1979, 95:14-23.

31. Ripka WL, Neves EB, Ricieri DV, Ulbricht L, Gewehr PM: Análise Fotogramétrica para Predição de Volume e Comportamento Respiratório em Adolescentes. In Book Análise Fotogramétrica para Predição de Volume e Comportamento Respiratório em Adolescentes, Volume 1. Porto de Galinhas: Anais CBEB; 2012:2258-2262. 2258-2262.

32. Guyton AC, Hall JE: Tratado de Fisiologia Médica. Rio de Janeiro: Elsevier; 2006.

33. Instituto Brasileiro de Geografia e Estatística - IBGE; [http://www.ibge.gov.br/]

doi:10.1186/1475-925X-13-21

Cite this article as: Ripka et al: Application of a photogrammetric kinematic model for prediction of lung

volumes in adolescents: a pilot study. BioMedical Engineering OnLine 2014 13:21.

\section{Submit your next manuscript to BioMed Central and take full advantage of:}

- Convenient online submission

- Thorough peer review

- No space constraints or color figure charges

- Immediate publication on acceptance

- Inclusion in PubMed, CAS, Scopus and Google Scholar

- Research which is freely available for redistribution

Submit your manuscript at www.biomedcentral.com/submit 